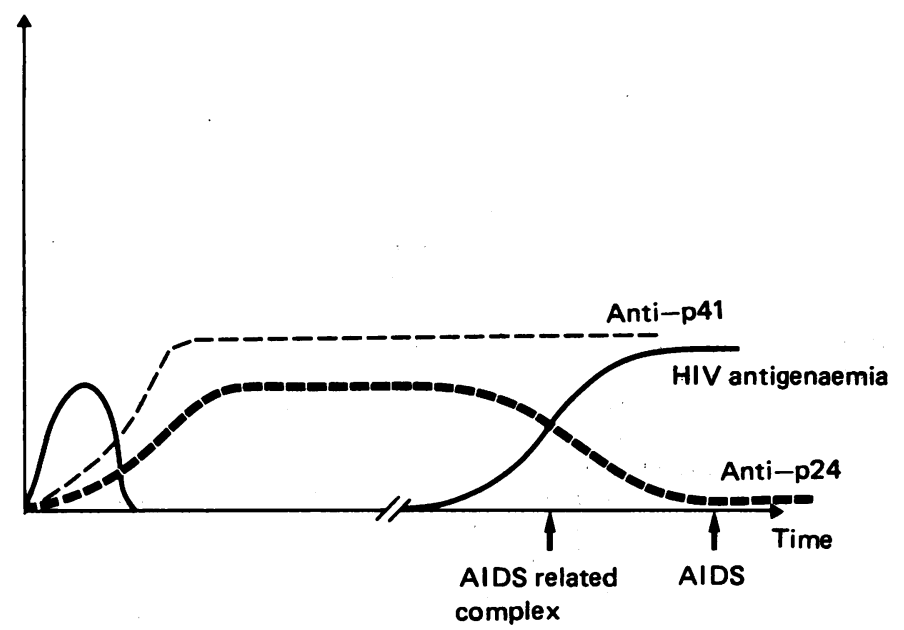

FIG 2-Serological profile of HIV infection.

patients, however, HIV antigen remains detectable after the primary infection' (Pedersen et al, unpublished).

The serological events during acute infection resemble those of other viral infections associated with antigenaemia, but the recurrence of antigenaemia and loss of anti-p24 during late stages of the infection are less readily explained. Loss of anti-p24 due to defective $B$ cell function is unlikely to be the initial event, as the production of antibodies directed against other HIV antigens remains intact. More probably loss of anti-p24 is secondary to the formation of antigen-antibody complexes due to increasing amounts of antigen in the late stages of the infection. This hypothesis is supported by the finding of HIV antigen in polyethylene glycol precipitated immune complexes both in patients with anti-p24 and in patients without detectable anti-p24 in serum. ${ }^{16}$

Our study shows that some patients develop antigenaemia within two years of infection while others remain healthy without antigenaemia for up to seven years. The reasons for the different courses remain obscure. Further studies of the serological profile in HIV infection, with special attention paid to events preceding antigenaemia and loss of anti-p24, may establish the role of possible cofactors for the progression of clinical disease.
Recurrence of HIV antigenaemia seems to indicate a poor prognosis. Kaplan-Meier curves (data not shown) show that $49 \%$ of patients will develop AIDS within two years from the reappearance of antigenaemia. This must be added to the long list of clinical, histological, immunological, and serological indicators of a bad prognosis. ${ }^{17}$ The ideal prognostic test must be simple to do and interpret. The antigen test fulfils these criteria and has the further advantage that it can be used in the form of a filter paper test, ${ }^{8}$ which may be of value in developing countries.

This study was supported by grants from the Michaelsen Foundation and the Danish State Medical Research Council.

\section{References}

1 Goudsmit J, Paul DA, Lange JMA, et al. Expression of human immunodeficiency virus antigen in serum and cerebrospinal fluid during acute and chronic infection. Lancet 1986;ii:177-80.

2 Allain JP, Laurian Y, Senn D. Serological markers in early stages of human immunodeficiency virus infection in haemophiliacs. Lancet 1986;ii:1233-6.

3 Wall RA, Denning DW, Amos A. HIV antigenaemia in acute HIV infection. Lancet 1987; ;:566.

4 Lange JMA, Paul DA, Huisman HG, et al. Persistent HIV antigenaemia and decline of HIV core antibodies associated with transition to AIDS. Br Med F 1986;293:1459-62.

5 Kenny C, Parkin J, Underhill G, et al. HIV antigen testing. Lancet 1987;i:565-6.

6 Pedersen $\mathrm{C}$, Kolby $\mathrm{P}$, Sindrup $\mathrm{JH}$, et al. Immunological studies in homosexual men with and without antibodies to human T-cell lymphotropic virus type III. Dan Med Bull 1986;33:270-2.

7 Centers for Disease Control, Atlanta. Classification system for human T-lymphotropic virus type III/ymphadenopathy associated virus infection. Ann Intern Med 1986;105:234-7.

8 Nielsen CM, Bygbjerg IC, Vestergaard BF. Detection of HIV antigens in eluates from whole blood collected on filter paper. Lancet 1987; i:566-7.

9 Dawson GJ, Heller JS, Decker RH, Valdivia LA. Confirmatory assay for antibodies to HTLV III Programs and abstracts of the II international conference on AIDS, Paris, 1986. Paris: Facimprim 1986:abstract No 642.

10 Gerstoft J, Malchow-Møller A, Bygbjerg I, et al. Severe acquired immunodeficiency in European homosexual men. BrMed f 1982;285:17-9.

11 Weber JN, Weiss RA, Roberts C, et al. Human immunodeficiency virus infection in two cohorts of homosexual men: neutralising sera and association of anti-gag amtibody with prognosis. Lancet 1987; i:119-22.

12 Kalyanaraman VS, Cabradilla CD, Getchell JP, et al. Antibodies to the core protein of lymphadenopathy-associated virus (LAV) in patients with AIDS. Science 1984;225:321-3.

13 Lange JMA, Coutinho RA, Krone WJA, et al. Distinct IgG recognition patterns during progression of subclinical and clinical infection with lymphadenopathy associated virus/human T-lymphotropic virus. BrMed f 1986;292:228-30.

14 Goudsmit J, Lange JMA, Paul DA, Dawson GJ. Antigenemia and antibody titers to core and envelope antigens in AIDS, AIDS-related complex, and subclinical human immunodeficiency virus infection. $\mathcal{I}$ Infect Dis 1987;155:558-60.

15 Biggar BJ, Melbye M, Ebbesen P, et al. Variation in human T lymphotropic virus III (HTLV III) antibodies in homosexual men: decline before onset of illness related to acquired immune deficiency syndrome (AIDS). Br Med F 1985;291:997-8.

16 Lange J, Goudsmit J. Decline of antibody reactivity to HIV core protein secondary to increased production of HIV antigen. Lancet 1987; i:448.

17 Anonymous. Who will get AIDS? [Editorial.] Lancet 1986;ii:953-4.

(Accepted 21 fuly 1987)

\title{
Risk of AIDS related complex and AIDS in homosexual men with persistent HIV antigenaemia
}

\author{
F DE WOLF, JAAP GOUDSMIT, DEBORAH A PAUL, JOEP M A LANGE, \\ CHRISTA HOOIJKAAS, PETER SCHELLEKENS, ROEL A COUTINHO, \\ JAN VAN DER NOORDAA
}

\begin{abstract}
One hundred and ninety eight men seropositive for human immunodeficiency virus (HIV) antibody and 58 HIV antibody seroconverters were studied for an average of 19.3 (SEM $0.5)$ months to assess the relation between HIV antigenaemia and the risk of developing the acquired immune deficiency syndrome (AIDS) and AIDS related complex. Forty (20.2\%) of the 198 HIV antibody seropositive men were antigen positive at entry and remained so during follow up. Eight $(13.8 \%)$ of the $58 \mathrm{HIV}$ antibody seroconverters and $20(12.7 \%)$ of the remaining $158 \mathrm{HIV}$ antibody seropositive men became antigen positive during follow up, resulting in an end point attack rate for HIV antigenaemia of $14 \cdot 3 \%$. AIDS related complex was diagnosed in $25(15.8 \%)$ of the
\end{abstract}

HIV antigen negative men and in $14(20.7 \%)$ of the HIV antigen positive men. AIDS was diagnosed in 15 men, resulting in an end point attack rate for AIDS of $23.9 \%$ in the HIV antigen positive group and $1.3 \%$ in the antigen negative group.

HIV antibody seropositive men without symptoms but with persistent HIV antigenaemia are at increased risk of developing AIDS and AIDS related complex.

\section{Introduction}

Human immunodeficiency virus (HIV) is the causative agent of the acquired immune deficiency syndrome (AIDS) and related 
disorders. ${ }^{1-4}$ Primary HIV infection is associated with transient changes in T4/T8 lymphocyte subsets, mainly due to an increase in the number of $\mathrm{T} 8^{+}$lymphocytes..$^{5 \cdot 7}$ Long term seropositivity for $\mathrm{HIV}$ antibodies is associated with inversion of the T4 to T8 ratio due to decreased numbers of $\mathrm{T}^{+}$cells, in some cases accompanied by an increase in $\mathrm{T}^{+}$cells. $^{8.11}$ Clinical disease develops in a large proportion of patients with long term seropositivity for HIV antibody.$^{10-13}$ In both transectional and longitudinal studies a grave clinical outcome appeared to be associated with the presence of HIV antigen and the decline of HIV core antibodies in serum..$^{14-17}$

We report a prospective study carried out over two years in which we determined the prevalence and incidence of HIV antigenaemia among HIV antibody seropositive $(n=198)$ and HIV antibody seroconverted $(n=58)$ homosexual men. The onset of clinical disease, classified according to the system used by the Centers for Disease Control, ${ }^{4}$ was studied in relation to the presence of HIV antigen in peripheral blood.

\section{Subjects and methods}

Between October 1984 and March 1986, 961 asymptomatic men living in and around Amsterdam and with at least two homosexual contacts in the preceding six months were enrolled in a prospective study of the prevalence and incidence of HIV infection and risk factors for AIDS. Epidemiological and clinical data were collected and blood sampled every three months. Of the 961 men, 723 were found to be HIV antibody seronegative and 238 HIV antibody seropositive in the first serum sample taken. The mean ages of the two groups were 34.9 (SEM 7.7) and 35.2 (6.9) years, respectively. During follow up 59 initially HIV antibody seronegative men seroconverted (end point attack rate for HIV antibody seroconversion $12.9 \%$ after 660 days). Forty HIV antibody seropositive men and one HIV antibody seroconverter failed to return for follow up at three or six months after entering the study. Sequential serum samples from the remaining 198 HIV antibody seropositive men and $58 \mathrm{HIV}$ antibody seroconverters were therefore collected between October 1984 and October 1986 and tested for HIV antigen. The mean age of these two groups was 35.1 (SEM 6.5) years and mean duration of follow up $19 \cdot 3$ (SEM 0.5 ) months.

HIV antigen seropositivity was defined as the presence of HIV antigen detected in three or more sequential serum samples taken over at least six months. Eleven of the $58 \mathrm{HIV}$ antibody seroconverters had HIV antigen transiently in serum before seroconversion and were included in the antigen negative group.

All subjects in the study were classified according to the Centers for Disease Control system for HIV infections. ${ }^{4}$

\section{DETECTION OF HIV ANTIBODIES AND HIV ANTIGEN}

Two commercially available enzyme linked immunosorbent assays (ELISA) with purified human T cell lymphotropic virus type IIIB used as antigen (Abbott Laboratories, Chicago; Vironostika Teknika, Organon,

Department of Virology, Academic Medical Centre, University of Amsterdam

F DE WOLF, MD, research fellow

JAAP GOUDSMIT, MD, PHD, virologist and chief of human retrovirus laboratory

JOEP M A LANGE, MD, internist

JAN VAN DER NOORDAA, MD, PHD, virologist and head of virology department

Department of Infectious Diseases, Municipal Health Service, Amsterdam CHRISTA HOOIJKAAS, statistician

ROEL A COUTINHO, MD, PHD, virologist and head of department

Abbott Laboratories, Diagnostic Division, North Chicago, Illinois, USA DEBORAH A PAUL, PHD, biochemist

Laboratory of Experimental and Clinical Immunology, University of Amsterdam, and Central Laboratory of the Netherlands Red Cross Blood Transfusion Service

PETER SCHELLEKENS, MD, PHD, immunologist

Correspondence to: Dr Jaap Goudsmit, Department of Virology, Room L-1-157, Academic Medical Centre, Meibergdreef 15, 1105 AZ Amsterdam, The Netherlands.
Oss, The Netherlands) were used to detect HIV antibody. Seropositivity was confirmed by immunoblotting, as described. ${ }^{16}$

Serum samples were assayed for HIV antigen in a solid phase immuno- 3 assay (Abbott Laboratories). Samples $(200 \mu \mathrm{l})$ were incubated overnight at $\varrho$ room temperature with human anti-HIV coated beads. Beads were then $c$ washed with distilled water, rabbit anti-HIV IgG was added, and the beads $\widehat{\widehat{O}}$ were incubated for four hours at $45^{\circ} \mathrm{C}$. Following this beads were washed as $\overline{\overline{5}}$ before then incubated for a further two hours at $45^{\circ} \mathrm{C}$ with goat antirabbit $]$ IgG conjugated to horseradish peroxidase. After a final wash beads were $\mathbb{D}$ transferred to tubes and $o$-phenylene diamine added. After 30 minutes at $m$ room temperature in the dark $1 \mathrm{~N}$ sulphuric acid was added to each tube. Optical density at $492 \mathrm{~nm}$ was read by the Quantum Dual Wavelength $\Rightarrow$ Spectrophotometer (Abbott Laboratories). A sample was considered $\stackrel{5}{\rightarrow}$ positive if its optical density was $\geqslant 0.050$ plus the mean of five duplicate readings in normal human plasma.

The solid phase immunoassay is especially sensitive for the core antigen of $\overline{\bar{c}}$. HIV, detecting antigen in culture supernatant of $10^{3}$ cells/l of HIV infected $\vec{\nabla}$ HT-9 cells (uninfected HT-9 cell supernatant is negative). The specificity of $\varrho$ the assay is determined in part by the rabbit antibody, which when used on $\%$ Western blots of purified HIV lysate or in radioimmunoprecipitation $\vec{\theta}$ procedures detects p55/24 (core) strongly and gp120/41 (env) only faintly. Purified recombinant core antigen is detectable at $50 \mathrm{ng} / \mathrm{l}$ when spiked into $\vec{\omega}$ serum or plasma, whereas purified recombinant env antigen is detectable at $\sigma$ roughly $500 \mu \mathrm{g} / \mathrm{l}$. We quantified HIV antigen by comparing the optical $\bar{O}$ densities of the samples with optical densities of known quantities of purified 3 . HIV lysate. With use of this antigen as a reference the detection limit of the $\tilde{\mathcal{O}}_{0}$ assay was approximately $20-30 \mathrm{ng} / \mathrm{l}$.

\section{STATISTICS}

Life table attack rates were calculated by the actuarial method. ${ }^{18} \mathrm{HIV} O$ antibody seroconverters were entered into intervals from the time of the first $\mathrm{G}$ HIV antibody seropositive serum sample and HIV antigen seroconverters $\mathcal{C}$ entered from the time of the first HIV antigen positive serum sample. Life $\mathbb{D}$ table attack rates were compared by using the statistics of Lee and Desu. ${ }^{19} \stackrel{\mathbb{D}}{\mathbb{D}}$ Other statistical methods used were $t$ tests and the $\chi^{2}$ test.

\section{Results}

Table I and figure 1 give the detailed and summarised data on HIV antigenaemia and the development of clinical disease.

\section{HIV ANTIGENAEMIA IN HIV ANTIBODY SEROPOSITIVE MEN}

Eight $(13.8 \%)$ of the $58 \mathrm{HIV}$ antibody seroconverters became HIV antigen positive at or shortly after seroconversion (fig 1, table I; group 2). Forty $(20.2 \%)$ of the $198 \mathrm{HIV}$ antibody seropositive men were HIV antigen positive (group 5 ) at entry to the study and $20(10 \cdot 1 \%)$ became HIV antigen positive (group 4) during follow up. In all HIV antigen seropositive groups the serum HIV antigen concentration increased significantly over time (group $2 \mathrm{p}<0.05$; group $4 \mathrm{p}<0.002$; group $5 \mathrm{p}<0.0001$ ) (table I). The end point attack rate after 660 days for HIV antigenaemia among HIV antibody seropositive men and HIV antibody seroconverters combined was $14.3 \%$ (fig 2).

\section{CLINICAL DISEASE AND HIV ANTIGENAEMIA}

AIDS related complex (Centers for Disease Control (CDC) classification IV-A) developed in $10(20.0 \%)$ of the 50 seroconverters without persisting HIV antigenaemia (fig 1, table I; group 1) and in $2(25.0 \%)$ of the eight $\vec{O}$ seroconverters with persisting antigenaemia (group 2). Among the HIV N antibody seropositive men $15(10.9 \%)$ in the HIV antigen seronegative group 0 (group 3), $5(25.0 \%)$ of the HIV antigen seroconverters (group 4), and $7(17 \cdot 5 \%)$ of the HIV antigen seropositive men (group 5) developed AIDS $\stackrel{\circ}{\square}$ related complex during follow up. Hence overall AIDS related complex $\stackrel{\mathbb{D}}{\mathrm{f}}$ developed significantly more frequently among HIV antigen seropositive men (groups 2, 4, and 5) than among HIV antigen seronegative men (groups 1 and 3) $(p<0.00001)$.

AIDS developed in $2(25.0 \%)$ of the eight seroconverters with HIV antigenaemia (group 2), in 2(1.4\%) of the 138 seropositive men without HIV $\mathbb{Q}$ antigenaemia (group 3), in $2(10.0 \%$ ) of the 20 seropositive men who became $\bar{\sigma}$ HIV antigen positive (group 4 ), and in $9(22.5 \%)$ of the 40 seropositive men with HIV antigenaemia at entry (group 5). Hence among the total group of $O$ 256 seropositive men 15 developed AIDS, representing an AIDS attack rate of $7 \cdot 8 \%$ after 660 days (fig 3). Two cases of AIDS occurred among HIV 
TABLE I-HIV antigenaemia and clinical disease in 256 homosexual men infected with HIV. (Study period October 1984 to October 1986)

\begin{tabular}{|c|c|c|c|c|c|c|c|c|c|}
\hline & \multicolumn{4}{|c|}{ HIV antibody seroconverters $(n=58)$} & \multicolumn{4}{|c|}{ HIV antibody seropositive men $(n=198)$} & \multirow[b]{2}{*}{ Total } \\
\hline & \multicolumn{2}{|c|}{$\begin{array}{c}\text { Group 1 } \\
\text { (antibody seronegative } \\
\rightarrow \text { antibody seropositive/ } \\
\text { antigen seronegative) }\end{array}$} & \multicolumn{2}{|c|}{$\begin{array}{c}\text { Group 2 } \\
\text { (antibody seronegative } \\
\rightarrow \text { antibody seropositive/ } \\
\text { antigen seronegative } \\
\rightarrow \text { antigen seropositive) }\end{array}$} & \multicolumn{2}{|c|}{$\begin{array}{c}\text { Group } 3 \\
\text { (antibody seropositive/ } \\
\text { antigen seronegative) }\end{array}$} & $\begin{array}{l}\text { Group } 4 \\
\text { (antibody seropositive/ } \\
\text { antigen seronegative } \\
\rightarrow \text { antigen seropositive) }\end{array}$ & $\begin{array}{l}\text { Group } 5 \\
\text { (antibody seropositive/ } \\
\text { antigen seropositive) }\end{array}$ & \\
\hline $\begin{array}{l}\text { No (\%) of men } \\
\text { Mean (SEM) duration (weeks) of: }\end{array}$ & \multicolumn{2}{|c|}{$50 / 58(86 \cdot 2)$} & \multicolumn{2}{|c|}{$8 / 58(13 \cdot 8)$} & \multicolumn{2}{|c|}{$138 / 198(69 \cdot 7)$} & $20 / 198(10 \cdot 1)$ & $40 / 198(20 \cdot 2)$ & $256(100 \cdot 0)$ \\
\hline $\begin{array}{l}\text { Antibody seropositivity } \\
\text { Antigen seropositivity }\end{array}$ & \multicolumn{2}{|c|}{$36 \cdot 7(5 \cdot 2)$} & \multicolumn{2}{|c|}{$\begin{array}{lr}45 \cdot 3 & (16 \cdot 0) \\
35 \cdot 3 & (7 \cdot 6)\end{array}$} & \multicolumn{2}{|c|}{$78 \cdot 6(6 \cdot 4)$} & $\begin{array}{l}85 \cdot 1(19 \cdot 1) \\
38 \cdot 3(4 \cdot 6)\end{array}$ & $\begin{array}{l}64 \cdot 4(2 \cdot 9) \\
64 \cdot 4^{(2 \cdot 9)}\end{array}$ & \\
\hline $\begin{array}{l}\text { Mean (SEM) HIV antigen concentration } \\
\text { (ng/l) in serum in: }\end{array}$ & & & & & & & & \\
\hline $\begin{array}{l}\text { First antigen seropositive sample } \\
\text { Last antigen seropositive sample }\end{array}$ & \multicolumn{2}{|c|}{$\overline{-}$} & \multicolumn{2}{|c|}{$\begin{array}{l}159 \cdot 1(85 \cdot 3) \\
547 \cdot 6(117 \cdot 7)\end{array}$} & \multicolumn{2}{|c|}{$\overline{-}$} & $\begin{array}{r}58 \cdot 6(25 \cdot 0) \\
160 \cdot 0(29 \cdot 7)\end{array}$ & \multirow[t]{2}{*}{$\begin{array}{l}232 \cdot 5(44 \cdot 4) \\
410 \cdot 5(53 \cdot 6)\end{array}$} & $\begin{array}{l}172 \cdot 6(30 \cdot 1) \\
354 \cdot 1(38 \cdot 8)\end{array}$ \\
\hline \multicolumn{9}{|l|}{ No (\%) of men with infections classified as: } & \\
\hline CDC I & 23 & $(46 \cdot 0)$ & 5 & $(62 \cdot 5)$ & & - & - & - & $(10 \cdot 9)$ \\
\hline CDC II & & $(32 \cdot 0)$ & 1 & $(12 \cdot 5)$ & 78 & $(56 \cdot 5)$ & $8(40 \cdot 0)$ & $11 \quad(27 \cdot 5)$ & $(44 \cdot 5)$ \\
\hline CDC III* & & $(48 \cdot 0)$ & & $(37 \cdot 5)$ & & $(31 \cdot 2)$ & $5(25 \cdot 0)$ & $13(32 \cdot 5)$ & $(34 \cdot 4)$ \\
\hline CDC IV-A* (AIDS related complex) & 10 & $(20 \cdot 0)$ & 2 & $(25 \cdot 0)$ & 15 & $(10 \cdot 9)$ & $5(25 \cdot 0)$ & $7(17 \cdot 5)$ & $(15 \cdot 2)$ \\
\hline CDC IV-C-1 (AIDS) & 0 & & & $(12 \cdot 5)$ & 1 & $(0 \cdot 7)$ & $2(10 \cdot 0)$ & $6(15 \cdot 0)\}$ & $(5 \cdot 9)$ \\
\hline CDC IV-D (AIDS) & $\mathbf{0}$ & & 1 & $(12 \cdot 5)$ & 1 & $(0 \cdot 7)$ & 0 & $\begin{array}{ll}3 & (7 \cdot 5)\}\end{array}$ & \\
\hline
\end{tabular}

$\mathrm{CDC}=$ Centers for Disease Control.

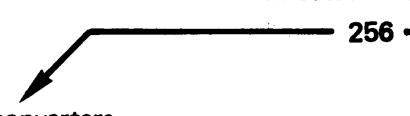

HIV antibody seroconverters

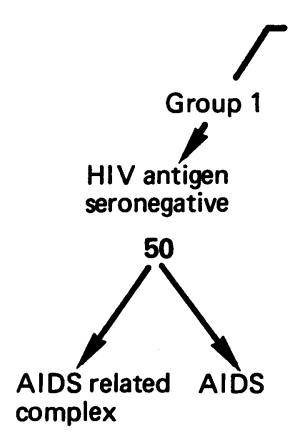

$10(20.0 \%) \quad 0 \quad 2(25.0 \%) \quad 2(25.0 \%) \quad 15(10.9 \%) \quad 2(1.4 \%)$

FIG 1-Diagrammatic summary of risk of AIDS related complex and AIDS in asymptomatic subjects with HIV antigenaemia.

HIV antibody seropositive men

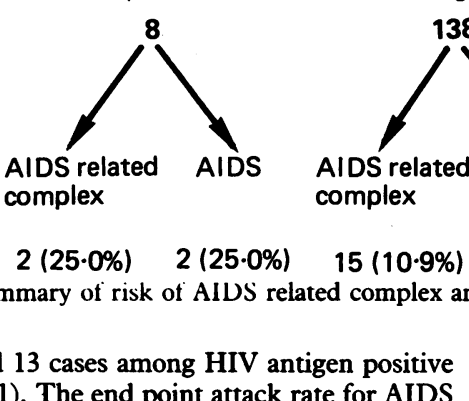
men (groups 2, 4, and 5; $<<0.00001$ ). The end point attack rate for AIDS after 660 days was $23.9 \%$ among HIV antigen seropositive men and $1 \cdot 3 \%$ among HIV antigen seronegative men ( $<<0 \cdot 00001 ; D=23 \cdot 292 ;$ fig 4).

The presenting diagnosis of AIDS was Pneumocystis carinii pneumonia (CDC IV-C-1) in 10 men, Kaposi's sarcoma (CDC IV-D) in four, and Burkitt's lymphoma (CDC IV-D) in one (table II). Nine of the $13 \mathrm{HIV}$ antigen seropositive men with AIDS remained HIV antigen seropositive throughout. The mean duration of HIV antigenaemia before AIDS was diagnosed in this group was 59.8 weeks (range 9-82 weeks; table II). Two men with AIDS (cases 3 and 6) from the HIV antibody seropositive cohort became HIV antigenaemic 35 and 13 weeks after entering the study and five

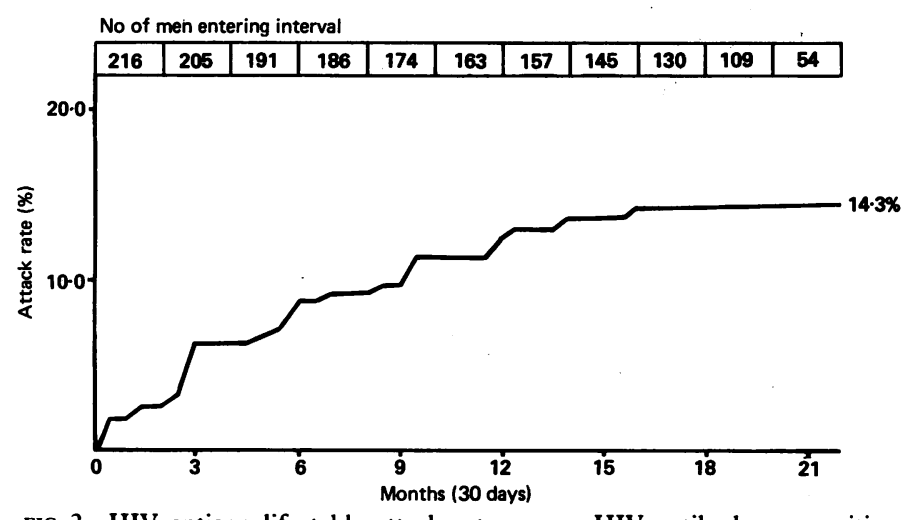

FIG 2-HIV antigen life table attack rate among HIV antibody seropositive homosexual men. (Study period October 1984 to October 1986.) and 29 weeks before AIDS was diagnosed. The remaining two cases of AIDS (cases 5 and 9) were in men who initially were HIV antibody seronegative. They became HIV antigenaemic 12 and six weeks after HIV antibody seroconversion and 12 and 60 weeks before AIDS was diagnosed. In cases 1 and 2 (table II) HIV antigen remained undetectable throughout the study.

\section{Discussion}

A high proportion of subjects infected with HIV develop immunological and clinical abnormalities during long term follow up. ${ }^{8.13}$ Previous studies have indicated that low values of HIV core antibodies in serum are associated with AIDS. ${ }^{1617}$ Declining levels of antibodies to core proteins may precede the development of AIDS by months to over a year. ${ }^{16}{ }^{17}$ Subsequent studies have shown that persistent HIV antigenaemia in conjunction with declining core antibodies may be associated with progression of disease. ${ }^{14} 152122$ This study extends our observations to the incidence of persistent HIV antigenaemia and the incidence of AIDS related complex and AIDS in relation to antigenaemia.

We found an increase in HIV antigen positivity among HIV antibody seropositive men with time resulting in an end point attack rate for HIV antigenaemia of $14 \cdot 3 \%$ after about two years. The interval between HIV antibody seroconversion and HIV antigen seroconversion varied widely. Repeated quantitative tests for HIV core antibody may help in identifying people prone to develop detectable amounts of HIV antigen as a decline of HIV core antibodies sometimes precedes HIV antigenaemia (J M A Lange et al, submitted for publication). Declining amounts of HIV core 


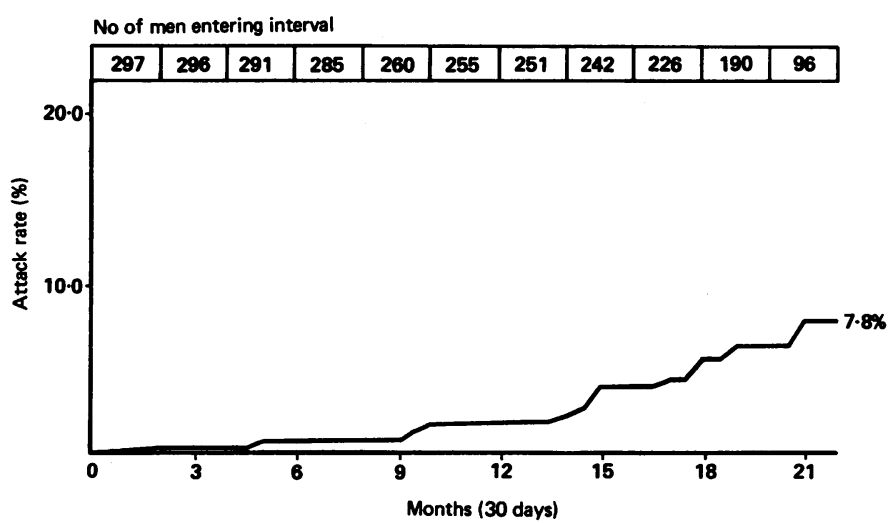

FIG 3-AIDS life table attack rate among HIV antibody seropositive homosexual men. (Study period October 1984 to October 1986.)

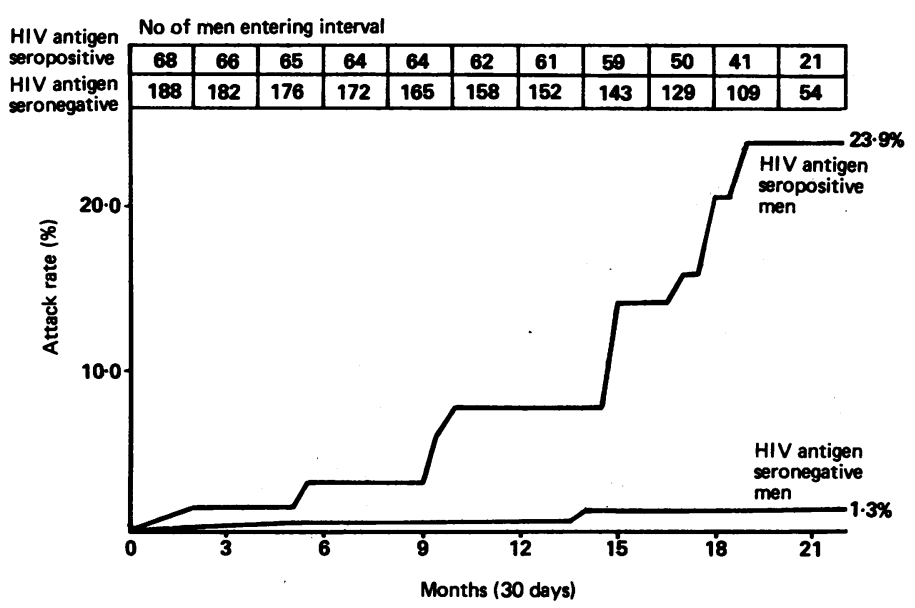

FIG 4-AIDS life table attack rates among HIV antibody/HIV antigen seropositive and HIV antibody seropositive/HIV antigen seronegative homosexual men. (Study period October 1984 to October 1986.)

TABLE II-HIV antigenaemia and clinical disease in 15 cases of AIDS

\begin{tabular}{|c|c|c|c|c|}
\hline \multirow[b]{2}{*}{$\begin{array}{l}\text { Case } \\
\text { No }\end{array}$} & \multicolumn{2}{|c|}{$\begin{array}{l}\text { HIV antigen concentration } \\
(\mathrm{ng} / \mathrm{l})\end{array}$} & \multirow{2}{*}{$\begin{array}{c}\text { Duration of } \\
\text { HIV antigenaemia } \\
\text { before diagnosis of AIDS } \\
\text { (weeks) }\end{array}$} & \multirow[b]{2}{*}{$\begin{array}{l}\text { Presenting } \\
\text { diagnosis }\end{array}$} \\
\hline & $\begin{array}{l}\text { First serum } \\
\text { sample }\end{array}$ & $\begin{array}{l}\text { Last serum } \\
\text { sample }\end{array}$ & & \\
\hline 1 & 0 & 0 & - & Burkitt's lymphoma \\
\hline 2 & 0 & 0 & - & P carinii pneumonia \\
\hline 3 & 0 & 26 & 5 & P carinii pneumonia \\
\hline 4 & 583 & 47 & 9 & Kaposi's sarcoma \\
\hline 5 & 0 & 350 & $12^{\star}$ & $P$ carinii pneumonia \\
\hline 6 & 0 & 259 & 29 & $P$ carinii pneumonia \\
\hline 7 & 166 & 116 & 42 & $P$ carinii pneumonia \\
\hline 8 & 28 & 35 & 44 & Kaposi's sarcoma \\
\hline 9 & 0 & 1071 & $60^{\star}$ & Kaposi's sarcoma \\
\hline 10 & 57 & 336 & 65 & $P$ carinii pneumonia \\
\hline 11 & 210 & 294 & 65 & P carinit pneumonia \\
\hline 12 & 294. & 1176 & 75 & P carinii pneumonia \\
\hline 13 & 40 & 151 & 77 & P carinii pneumonia \\
\hline 14 & 275 & 280 & 79 & $P$ carinii pneumonia \\
\hline 15 & 231 & 589 & 82 & Kaposi's sarcoma \\
\hline
\end{tabular}

${ }^{\star} \mathrm{HIV}$ antibody/HIV antigen seroconverter.

antibodies indicate trapping of these antibodies by HIV antigen in immune complexes. ${ }^{23}$ The assay that we used detects "free" antigen remaining once the amount of HIV core antibody has been exhausted.

Most HIV antibody seropositive men without HIV antigenaemia remained symptom free during follow up. In addition, persistent generalised lymphadenopathy (CDC III) was as prevalent among HIV antigen negative as among HIV antigen positive men. AIDS related complex and AIDS, however, were seen more frequently among HIV antigen positive than among HIV antigen negative men. The incidence of AIDS in our study was some 20 times higher among men who were HIV antigen positive than among those who were HIV antigen negative.

Two cases of AIDS occurred in the HIV antigen seronegative group. One patient had Burkitt's lymphoma and subsequently died, and the other had $P$ carinii pneumonia and remained well after treatment. In sequential serum samples from both subjects circulating immune complexes containing HIV antigen were detected..$^{23}$

The duration of HIV antigenaemia before the diagnosis of AIDS varied from five to 82 weeks, ruling out any possibility of predicting the time interval between HIV antigen positivity and the development of AIDS. The same was true for the concentration of HIV antigen; high as well as low concentrations of HIV antigen were detected in those who went on to develop AIDS and in those who did not over the same period.

In conclusion our data show that the incidence of HIV antigen positivity increases with time and that the attack rate of AIDS is significantly higher among HIV antigen seropositive men than among HIV antigen seronegative men. The identification of these subgroups of HIV antibody seropositive and symptomless men with distinguishable risks for AIDS is important; it opens the way to predict future cases of AIDS more accurately and to select subjects infected with HIV for trials of antiviral drugs that effectively reduce the viral antigen load aiming at preventing AIDS rather than treating AIDS.

We thank Nel Albrecht-van Lent, Roos Lopez-Dias, Kiki Nittel, Emilie Nord, Margreet Bakker, Lia Smit, Sylvia Teengs, Marijke Roos, and David Mack for technical help and Riet de Krieger-Reumkens for preparing the manuscript. This study was partly supported by grant No 281026 of the Netherlands Foundation for Preventive Medicine.

\section{References}

1 Wong-Staal F, Gallo RC. Human T-lymphotropic retroviruses. Nature 1985;317:395-403. 2 Gallo RC, Salahuddin SZ, Popovic M, et al. Frequent detection and isolation of cytopathic retroviruses (HTLV-III) from patients with AIDS and at risk for AIDS. Science 1984;224: 500-3.

3 Levy JA, Shimabukuro J. Recovery of AIDS-associated retroviruses from patients with AIDS or AIDS-related conditions and from clinically healthy individuals. I Infect Dis 1985;152:734-9. AIDS-related conditions and from clinically healthy individuals. F Infect Dis 1985;152:734-9.
Centers for Disease Control. Classification system for human T-lymphotropic virus type Centers for Disease Control. Classification system for human T-lymp
III/lymphadenopathy associated virus infections. MMWR 1986;35:334-9.

Cooper DA, Gold J, Maclean P, et al. Acute AIDS retrovirus infection: definition of a clinical illness associated with seroconversion. Lancet 1985;i:537-40.

6 Tucker J, Ludlam CA, Craig A, et al. HTLV-III infection associated with glandular-fever-like illness in a haemophiliac. Lancet 1985; 585 .

Piette AM, Tusseau F, Vignon D, et al. Acute neuropathy coincident with seroconversion for anti-LAV/HTLV-III. Lancet 1986;i:852.

8 Jaffe HW, Feorino PM, Darrow WW, et al. Persistent infection with human T-lymphotropic virus type III/lymphadenopathy associated virus in apparently healthy homosexual men. Am Intern Med 1985;102:627-8.

9 Schwartz K, Visscher BR, Detels R, Taylor J, Nishanian P, Fahey JC. Immunological changes in lymphadenopathy virus positive and negative symptomless male homosexuals: two years of observation. Lancet 1985;ii:831-2.

10 Melbye M, Biggar RJ, Ebbessen P, et al. Long term seropositivity for human T-lymphotropic virus type III in homosexual men without the acquired immunodeficiency syndrome: development of immunological and clinical abnormalities. Ann Intern Med 1986;104:496-500.

11 Weber JN, Wedworth J, Rogers LA, et al. Three-year prospective study of HTLV-III/LAV infection in homosexual men. Lancet 1986; i:1179-82.

12 Jaffe HE, Darrow WW, Echenberg DF, et al. The acquired immunodeficiency syndrome in a cohort of homosexual men. A six year follow-up study. Ann Intern Med 1985;103:210-4.

13 Goedert JJ, Biggar RJ, Weiss $\mathrm{H}$, et al. Three-year incidence of AIDS in five cohorts of HTL V-III-infected group members. Science 1986;231:992-5.

14 Goudsmit J, Wolf F de, Paul DA, et al. Expression of human immunodeficiency virus antigen (HIV-Ag) in serum and cerebrospinal fluid during acute and chronic infection. Lancet (HIV-Ag) in

15 Lange IMA, Paul DA, Huisman HG, et al. Persistent HIV antigenaemia and decline of HIV core antibodies associated with transition to AIDS. BrMed $\mathcal{J}$ 1986;293:1459-62.

16 Lange JMA, Coutinho RA, Krone WJA, et al. Distinct IgG recognition patterns during progression of subclinical and clinical infection with lymphadenopathy associated virus/human T-lymphotropic virus. BrMed J 1986;292:228-30.

17 Weber JN, Clapham PR, Weiss RA, et al. Human immunodeficiency virus infection in two cohorts of homosexual men: neutralising sera and association of anti-gag antibody with prognosis. Lancet 1987; i:119-22.

18 Berkson G, Gage R. Calculation of survival rates for cancer. Proceedings of the Staff Meetings of the Mayo Clinic 1950;25:270.

19 Lee E, Desu M. A computer program for comparing k samples with right-sensored data. Computer Programs in Biomedicine 1972;2:235-321.

20 Taylor JMG, Schwartz K, Detels R. The time from infection with human immunodeficiency virus (HIV) to the onset of AIDS. F Infect Dis 1986;154:694-7.

21 Goudsmit J, Lange JMA, Paul DA, Dawson GJ. Antigenemia and antibody titers to core and envelope antigens in AIDS, ARC, and subclinical HIV infection. $\mathcal{I}$ Infect $D$ is 1987;155:558-60.

22 Goudsmit J, Lange JMA, Krone WJA, et al. Pathogenesis of HIV and its implications for serodiagnosis and monitoring of antiviral therapy. $\mathcal{F}$ Virol Methods (in press).

23 Lange JMA, Paul DA, de Wolf F, Coutinho R, Goudsmit J. Viral gene expression, antibody production and immune complex formation in human immunodeficiency virus infection. AIDS 1987;1:15-20.

(Accepted 7 fuly 1987)

\section{高}

